DOI : 10.24260/khatulistiwa.v8i2.1248

\title{
POST-BIRTH CUSTOM ON MALAY PEOPLE IN JONGKONG KAPUAS HULU
}

\author{
Kartono \\ Ministry of Religion Affairs \\ Email: abahkartono78@gmail.com
}

\section{HIGHLIGHT}

- Islam and Local Culture

- $\quad$ Ritual of Give Birth

- Malay people of West Kalimantan

\begin{tabular}{|c|c|}
\hline ARTICLI & HISTORY \\
\hline Submitt & : 5 Feb 2018 \\
\hline Revision & : 2 Mar 2018 \\
\hline Revision & : 15 Mar2018 \\
\hline Minor & \\
\hline Accepted & : $\quad 4$ May 2018 \\
\hline Published & : $\quad 2$ Sep 2018 \\
\hline
\end{tabular}

Keyword:

\begin{abstract}
This article discusses the traditional knowledge of society is the wealth of inheritance obtained from previous generations.. In this element there are beliefs that are associated with supernatural powers, and there are also beliefs that are associated with science. Explanation of these two aspects often cannot be done because of a limited understanding of the culture of the community. Instead of culture that is sustainable, often culture is abandoned because it is considered a prohibited work. Taking examples of activities 40 days after giving birth, this article explains the transition of cultural aspects from belief to knowledge. That is why the response to local culture must be preceded by deepening before any attitude is given.
\end{abstract}

Malay Culture, Local Wisdom, Embau Malay

(C)2018 Khatulistiwa All Rights Reserved

KHATULISTIWA: Journal of Islamic Studies Vol. 8, No. 2. September 2018
DOI: 10.24260/khatulistiwa.v8i2.1248

Post-Birth Custom on Malay People in Jongkong Kapuas hulu 


\section{A. INTRODUCTION}

The human life cycle is a necessity in one's life and everyone cares about it. Some people greet that momentum with a special event. Customary births, towards adulthood, entering adulthood, marriage, and death are greeted almost in all societies with certain events and ways.

These events are not only considered as important moments, which will not be repeated in their life, but sometimes it has special meanings (Keesing, R, 1992). Meaning or purpose can only be captured or understood by communities as the subject. For example, in certain communities, the implementation of certain activities is carried out, purely carrying out ancestral heritage. They will feel guilty if they do not continue the tradition. In other communities, certain activities are carried out because they consider that the activity has a social value. A person prestige is determined by how someone greet or celebrate that momentum. The more fabulous and festive is better. The more crowded people who come or the more luxurious the service will make the host considered as great people and high social status in the society. (See Yusriadi, 2015).

On the other hand, the momentum of celebration in the life cycle is maintained because members of the public view that the celebration as a medium for generating togetherness, group solidity, social communication, and genealogy maintenance.

Therefore according to Liliweri (2003) in every culture there is always something behind it. Culture is a symbol of something or a sign for something in that community.

Culture in each community must be considered the best human creation in its time. Something inherited and something that is carried out because of certain considerations; especially the consideration of good and bad.

KHATULISTIWA: Journal of Islamic Studies Vol. 8, No. 2. September 2018
DOI: 10.24260/khatulistiwa.v8i2.1248

Post-Birth Custom on Malay People in Jongkong Kapuas hulu 
This simple article will discuss how to implement a birth culture of Malay communities in Jongkong, Kapuas Hulu, West Kalimantan. This culture is a part of the life cycle in society.

\section{B. METHOD}

This study is ethnographic study. This study starts from researcher's interest to study about society life, in this case Malay community in Jongkong. Researcher views that Jongkong Malay is a unique community: Malays live in inland area that have been known as area of Dayak people. (King, 1993). The number of them is also the majority in this region. Even in the direction of Embau -Jongkong River located in the mouth of this river, 100 percent are Muslims. (Yusriadi, 2007)

The researcher collected data through interviews and observations. Data was obtained from Jongkong residents in Kapuas Hulu; including midwives or traditional midwives and Jongkong residents who are considered to know well about this tradition. Data from interviews and observations are then classified according to the interests of this study, in accordance with sub-sections and then described. That description is presented to the reader as seen in this article.

\section{RESULT AND DISCUSSION}

\section{Description of Jongkong}

Jongkong is one of the inland areas in West Kalimantan. Distance from Pontianak is about 600 kilometers to the east. It can be reached by land transportation for about 14 hours

Jongkong environtment in the inland area of West Kalimantan resembles a crater with a lower land especially in the north. This lower land is the lakes connected from Kanung Suli lake to the famous Sentarum lake. On the edges of the lake are growing wilderness and shrubs which impress Jongkong environtment surrounded

KHATULISTIWA: Journal of Islamic Studies Vol. 8, No. 2. September 2018
DOI: $10.24260 /$ khatulistiwa.v8i2.1248

Post-Birth Custom on Malay People in Jongkong Kapuas hulu 
by forests. Jongkong, as part of Kapuas Hulu, is known as a conservation district which is a protected forest area. (Pontianak Post, 2015).

The population of Jongkong for about 13,000 people. They are Malays. According to Collins, who quoted Dutch sources, Jongkong was mentioned in the early 19th century writings. Jongkong people were already acquainted with Islam at that time. (Collins, JT. 2003).

Jongkong is known as the center of Islam in the inland area. The presence of Islamic religious schools (Madrasah Ibtidaiyah, Tsanawiyah and Aliyah) is a religious education institution for the entire population in Jongkong and surrounding areas (Yusriadi, 2018, Hermansyah, 2006). Ustad H. Ahmad, et al. as a religion teacher, is the main character in the maintenance and development of Islam here. Later, their students become religious officers in many villages in this inland area.

Jongkong people profession generally are fishermen, farmers, laborers, and employees. (Yusriadi, 2018). Fish in Kapuas River and several lakes in the north and west of Jongkong are the main place. Fish and processed production from Jongkong and surrounding areas supplies fish resources for inland area. Even some of it is supplied to Sintang and Pontianak. Including siluk or arwana fish, a type of ornamental fish that is very expensive, is an economic icon of Jongkong and its surroundings.

In addition, nowadays the profession of many people also depends a lot on swallow cultivation by making swallow houses. Almost every village in the inland area, along Kapuas river, there are many swallow houses. High prices make the enthusiasm of the people to develop this cultivation increases.

The attention of Jongkong Malay community towards culture is very high. In fact, there has been an increase lately. Customary institutions are recognized and customary law is still applied. Temenggung has legitimacy in society. This situation is considered to provide value to the existence of Malay. On the other hand, culture

KHATULISTIWA: Journal of Islamic Studies Vol. 8, No. 2. September 2018
DOI: $10.24260 /$ khatulistiwa.v8i2.1248

Post-Birth Custom on Malay People in Jongkong Kapuas hulu 
related to aspects of trust began to be abandoned a lot. People begin to no longer believe in things that are unseen; for examples about invisible guide, gana, and duwata. The culture related to the supernatural power has been lost in some parts.

\section{Birth Process and 40 Days After Birth}

Based on the ancestral beliefs of Jongkong Malay community that after giving birth, a village midwife, who was a companion when they were about to give birth, assisted the childbirth when the child born. The placenta which was still attached to the baby is crumpled and sorted with intend to sorted the food in the placenta into the baby's stomach and the baby will not feel hungry fo a few days later. Next, midwife cut the cord of placenta with a lump, bamboo skin made like a knife and very sharp once, with the purpose that the baby is not easily hurt or protected from danger of sharp weapons or tools except sembilu (a very sharp bamboo skin).

After the placenta is cut, the village midwife cleans and bathes it and then wraps it with a white cloth, then straddles it with a cloth and immediately plants or buries the placenta in a special place usually at the side of the house or under the house. It is accompanied by reading selawat to Prophet Muhammad for three times.

Then the family proceeded to perform the ritual, namely lighting a lantern lamp (petromak) under the house for 40 days. Before putting the lights under the house, the parents must read Momang (pray) as for the reading is:

"I intentionally put a lamp to keep the newborn baby child so that the child is not crying and the child is not touched by spirits."

The lights are only turned on at night. During the day or in the morning, the lights are turned off. The aims and objectives are:

1. Let the baby does not cry easily

2. The house is kept from spirits

3. For the baby's mother to stay safe

4. Prevent bad things for the newborn baby

KHATULISTIWA: Journal of Islamic Studies Vol. 8, No. 2. September 2018
DOI: 10.24260/khatulistiwa.v8i2.1248

Post-Birth Custom on Malay People in Jongkong Kapuas hulu 
5. Let the baby does not feel convulsions

\section{Relation to Islam}

Local culture among Malay people is always related to Islam. At least, that is the customary principle used in Malay society: adat bersendi syara', syara' bersendi kitabullah (custom refereed to syara', syara' referred to kitabullah)

In this tradition, there is a very good effort or intention from cultural subject. Absolutely with all these efforts and intentions, the mother and baby always get safety from spirits and to avoid all kinds of dangers that threaten the safety of mother and baby.

The meaning of intention itself is the intention or strong desire from the heart to do something. In syar'i terminology means the desire to obey Allah by carrying out actions or leaving them.

Intention includes the actions of the heart so the place is in the heart, even all the actions that the human being wants to do. The intentions are automatically embedded in the heart.

There are three aspects of intention:

1) Believed in the heart.

2) Pronounced verbally (no need to be loud so that it can disturb others or even become riya).

3) Performed with deeds.

With this definition of intention, it is expected that Muslims will not only "talk" when intending something means the unity between heart, speech and deeds. The good intentions of a Muslim will of course come from a heart that is khusyu' and 'tawadhu', good and polite speech, and actions that are carefully thought out, unhurried and accurate. The Prophet sallallaahu alaihi wasallam said:

KHATULISTIWA: Journal of Islamic Studies Vol. 8, No. 2. September 2018
DOI: 10.24260/khatulistiwa.v8i2.1248

Post-Birth Custom on Malay People in Jongkong Kapuas hulu 


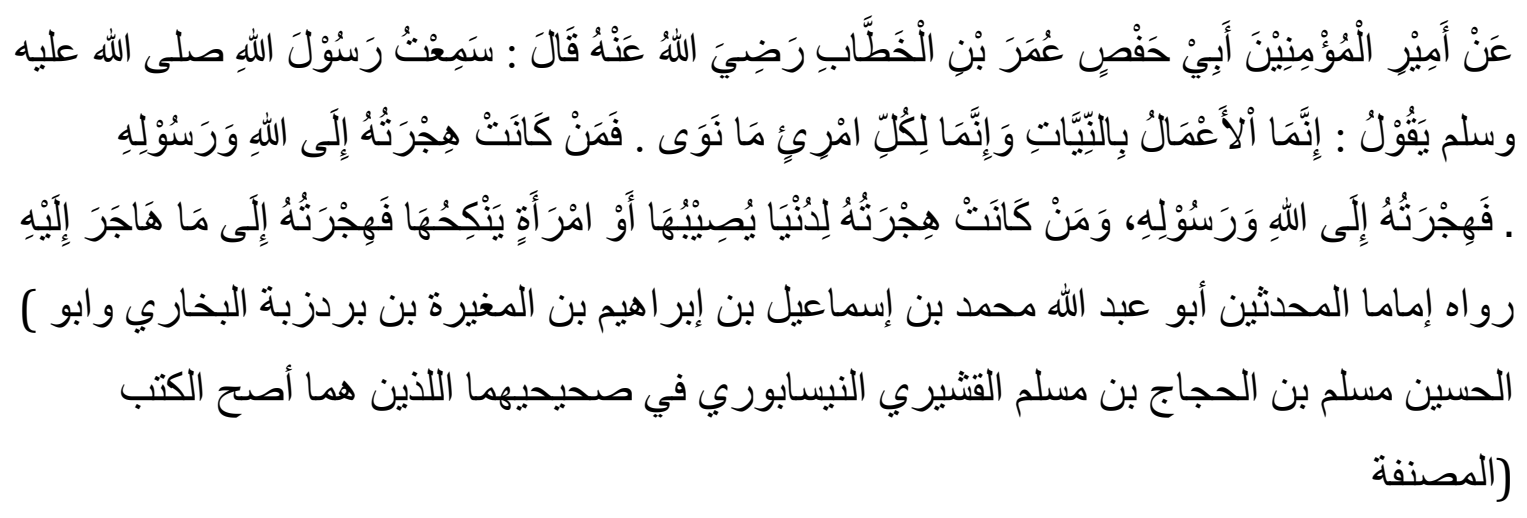

Meaning:

From Amirul Mu'minin, (Abu Hafsah or Umar bin Khattab rodiyallohu'anhu) he said: "I have heard the Messenger of Allah shollallohu'alaihi wassalam said: 'Surely all the charity depends on his intention, and everyone will get according to his intention. Therefore, whoever emigrated because of Allah and His Messenger, then moved to Allah and His Messenger. And whoever emigrates because of (to get) the world or because of the woman he wants to marry, then his hijrah is to what is the goal (intention)"

Narrated by two imam of hadith experts; Abu Abdillah Muhammad ibn Ismail ibn Ibrohim ibn Mughiroh bin Bardizbah Al-Bukhori and Abul Husayn Muslim ibn AlHajjaj bin Muslim Al-Qusairy An-Naisabury in their two books which are the most authentic books among hadith books.

Ulama (Islamic scholars) have given opinions on this matter. Imam Ibn Rajab said: "Ulama agreed on their saheeh and ummah had agreed to accept it".

Imam Ibn Daqiqil 'Ied said in Syarh Arbain An-Nawawi p. 9: "This is a legitimate hadith which is agreed on his saheeh and the magnitude of his position and majesty also the benefits". Abu Ubaid said: "None of the hadiths of the Prophet Shollallahu 'alai wa 'ala alihi wasallam, are more adequate and more useful than this hadith". And it had been agreed on imam such as Abdurrahman bin Mahdi, Ash-Sy afi'iy, Ahmad bin Hanbal, 'Ali Ibnul Madini, Abu Dawud As-Sijistani, At-Tirmidzy, Ad-Daraquthny and Hamzah Al-Kinani that this hadith is one third of knowledge.

KHATULISTIWA: Journal of Islamic Studies Vol. 8, No. 2. September 2018
DOI: 10.24260/khatulistiwa.v8i2.1248

Post-Birth Custom on Malay People in Jongkong Kapuas hulu 
This was commented by Imam Al-Baihaqi with his words: "This is because the actual practice of a servant is with his heart, his verbal and body parts, while intention is one of the three parts".

Abdurrahman bin Mahdiy said: "This hadith about intention can be included in 30 chapters of science". While Imam Asy-Syafi'iy said that this hadith could be included in 70 chapters of fiqhi. Regarding the words of the Prophet, "all the deeds depend on their intentions" there are many differences of opinion among ulama about the purpose of the sentence. Some understand the intention as a condition so that charity is invalid without intention, others understand the intention to be perfect so that the charity will be perfect if there is intention.

Based on the basic law above, it means that customs like this can still be maintained because there are many various efforts with good intentions to get the goodness and safety from both the baby and the new mother.

\section{CONCLUSION}

The tradition of greeting baby birth and 40 days after birth in Malay society in Jongkong is one of the traditions that are considered important in the life cycle of the community. A newborn baby and a woman who has just given birth are weak and therefore need to be strengthened by giving her a protection. Prayer is an endeavor in seeking protection.

Even though this tradition has been rejected by some groups, it shows the positive side. The people and family who carry out this event is for the good intentions of themselves and their families. In addition, this activity also provides good value, that is, connecting relationships between communities, helping each other and working together.

In the terms of Islam, the implementation of such kindness is not a mistake. In fact, in some histories, it is recommended. This is where we see that the cultural values

KHATULISTIWA: Journal of Islamic Studies Vol. 8, No. 2. September 2018
DOI: $10.24260 /$ khatulistiwa.v8i2.1248

Post-Birth Custom on Malay People in Jongkong Kapuas hulu 
that grow and develop in the community have a good side, and therefore these values are inherited. This fact shows that any response to local culture, must be preceded by deepening before the attitude - especially the attitude of rejecting something is delivered.

KHATULISTIWA: Journal of Islamic Studies

Vol. 8, No. 2. September 2018
DOI: $10.24260 /$ khatulistiwa.v8i2.1248

Post-Birth Custom on Malay People in Jongkong Kapuas hulu 


\section{BIBLIOGRAPHY}

Arafah, B. (2003). Warisan Budaya, Pelestarian dan Pemanfaatannya. Artikel, Fakultas Ilmu Budaya UNHAS.

Collins, JT. (2003). Orang Embau dan Masyarakat Melayu, dalam Yusriadi dan Hermansyah. Orang Embau, Potret Masyarakat Pedalaman Kalimantan. Pontianak: STAIN Pontianak Press.

Keesing, R. (1992). Antropologi Budaya.Jakarta: Erlangga.

King, V. (1993). The People of Borneo. Oxford UK: Blackwell.

Liliweri, A. (2003). Makna Budaya dalam Komunikasi antarbudaya. LkiS Pelangi Aksara.

Hermansyah. (2006). Alam Orang Melayu: Kajian Ilmu di Embau, Kalimantan Barat. Disertasi, Institut Alam dan Tamadun Melayu, Universiti Kebangsaan Malaysia.

Pontianak Post, (2015). Kapuas Hulu Kabupaten Konservasi, Sebagai Paru-paru Dunia. Pontianak Post 19 Desember 2015.

Yusriadi, Y. (2007). Dialek Melayu Ulu Kapuas. Kuala Lumpur: Dewan Bahasa dan Pustaka.

Yusriadi, Y. (2015). Identitas Orang Melayu di Hulu Sungai Sambas. Khatulistiwa No 5 (1): 74-99.

Yusriadi, Y. (2018). Jongkong, Potret Perubahan Masyarakat Pedalaman Kalimantan. Pontianak: IAIN Pontianak Press.

Informants:

Abdul Nasir, 26 years old, Jongkong.

Nyang Sidoi, 50 years old, Jongkong.

Abang, 45 years old, Jongkong.

KHATULISTIWA: Journal of Islamic Studies Vol. 8, No. 2. September 2018
DOI: 10.24260/khatulistiwa.v8i2.1248

Post-Birth Custom on Malay People in Jongkong Kapuas hulu 